20.

\title{
シネ用自動現像機JAMIESON MODEL-54について
}

一臨㕅適用のための改良一

\begin{tabular}{|c|c|c|}
\hline 国立循環器病センター & $\begin{array}{l}\text { ○粟并一夫 } \\
\text { (KAZUOAI) }\end{array}$ & $\begin{array}{l}\text { 若松孝司 } \\
\text { (T.WAKAMATU) }\end{array}$ \\
\hline & $\begin{array}{l}\text { 小林美三男 } \\
\text { (M. KOBAYAHI) }\end{array}$ & $\begin{array}{l}\text { 橋本時弘 } \\
\text { (T. HASHMOTO) }\end{array}$ \\
\hline & $\begin{array}{l}\text { 福西康修 } \\
\text { (Y. FUKUNISHI) }\end{array}$ & $\begin{array}{l}\text { 永井辰江 } \\
(T \text { NAGAI) }\end{array}$ \\
\hline コダックナガセ㑣 & $\begin{array}{l}\text { 鎌江春囊 } \\
\text { (H. KAMAE) }\end{array}$ & \\
\hline
\end{tabular}

東儀英明
(H. TOGI) 佐野敏也
(T.SANO)

鄭明子松井泰伸

横山博典柴組一男

【はじめに】我っの施設では高感度高コントラストシネフィルムを臨床使用していた。これはX線 挂犆の容量もさることながら、大量のフィルムを迅速に処理出来るという当センターの需要に合致し 留直の谷量もがほかになかったという理由が大きい。さて、これからのシネフィルムには微細血管まで 描出できる能力が要求さ机てくる。しかし従来出回っていた微粒子フィルムはクリアベースであり こ加は当セン夕ーの要求に合致しないものである。最近我々の要求を满足するブルーベースの微粒子 フィルムが出現した。ところが従来のシネ自現機では低感度微粒子フィルムを大量迅速処理できない そこで、それらのフィルムを大量迅速処理可能なJAMIESON MODEL-54を導入した。しかし実際にこ の自現機を使用してみると数々の不都合な点が見つかった。そこで我々は、JAMIESONの性能を最大限 に生かしつつNX-2の簡便性を取り入れるような改良を加えたので報告する。

【改良点】改良の目的は 1) 高速で安定したフィルム搬送と 2) 使い易さである。下図左がJAMIES ON MODEL-54、右が撮影したフィルムを巻き取るオートフィルムローダーである。改良箇所を以下に 示古。

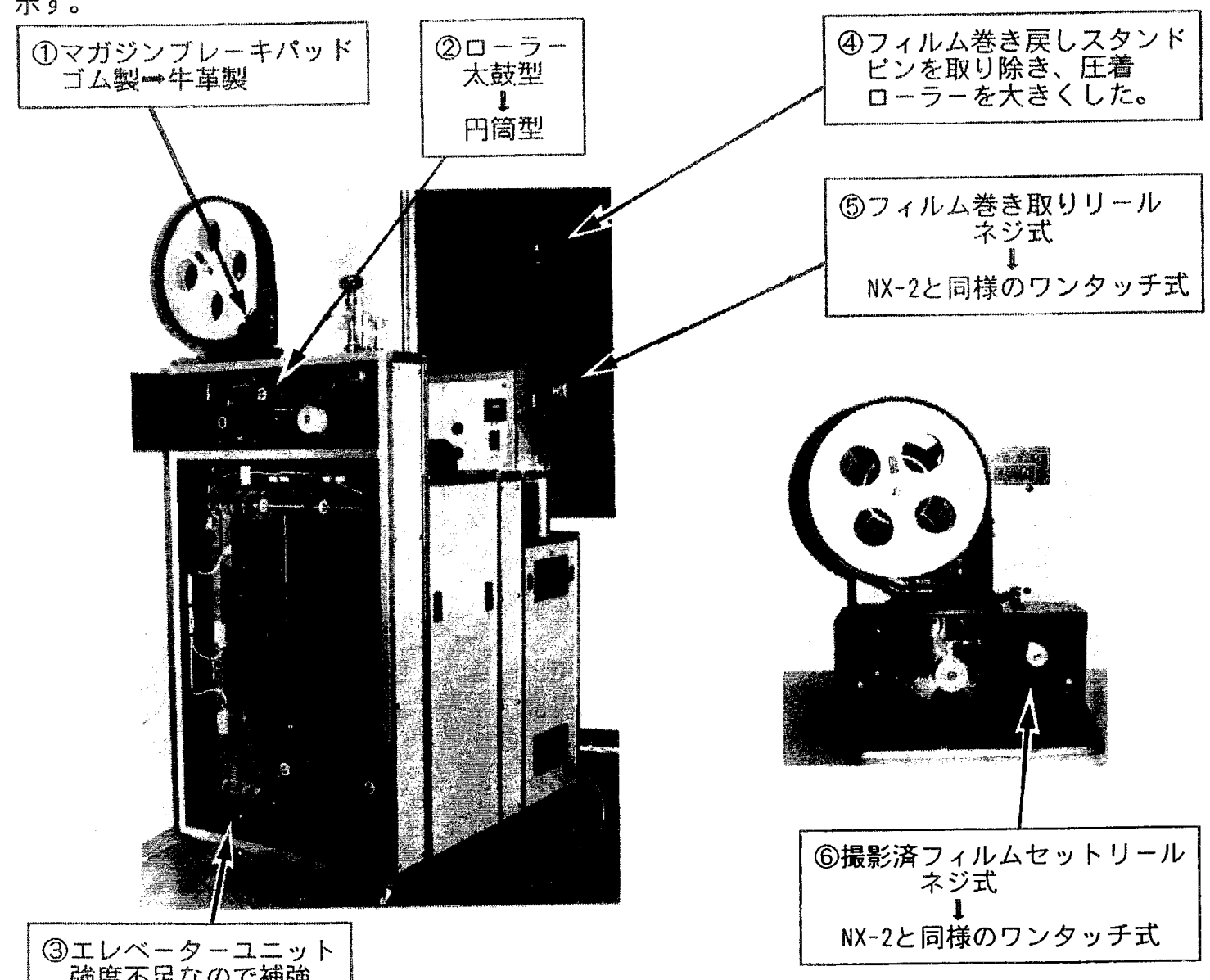

强度不足なので補強

【結果】JAMIESON MODEL-54 の現像性能は定評あるところであるが、現像操作はNX-2を使い慣れたも のにとって非常に煩雑なものである。今回、加えた改良によって現像性能を低下させることなく去 記(1)(2)の改良によって不安定だったフィルムの搬送性が改善され、(4)(5)(6)の改良によって作業能率 を向上させることに成功した。 